\section{Hva som gikk galt med evidensbasert medisin}

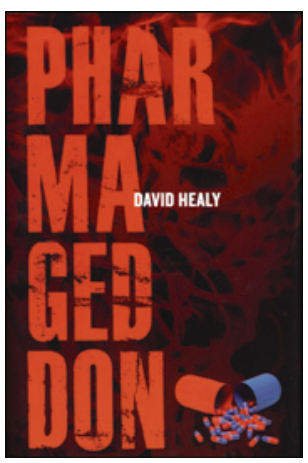

David Healy

Pharmageddon

302 s. Berkeley, CA: University of California

Press, 2012. Pris USD 40

ISBN 978-0-520-27098-5

Behandling med legemidler skal være tuftet på dokumentert kunnskap om effekt og bivirkninger. I et par tiår har vi hatt Cochranesystemet for systematiske kunnskapsoppsummeringer. Både her og andre steder benytter man prinsippene fra evidensbasert medisin (EBM) for vektlegging av kunnskap. I dette hierarkiet representerer systematiske oversikter/metaanalyser og randomiserte, kontrollerte studier kunnskapens gullstandard. Det er slik kunnskap man skal basere terapeutiske retningslinjer på.

På legemiddelområdet er det imidlertid blitt stadig tydeligere at også evidensbasert medisin er infisert av «results biased medicine». De mange skjevhetene og manglene i publisert kunnskap om nye legemidler gjør at også troverdigheten til systematiske kunnskapsoppsummeringer svekkes.

Hvorfor og hvordan det er blitt slik, kan man lese i Pharmageddon. Tittelen er et ordspill på Armageddon, som nærmest betyr ragnarokk eller det endelige slaget mellom det onde og det gode før dommedag. Her handler det imidlertid om hvordan farmasøytisk industri nå kontrollerer legemiddelforskningen, slik at forskning og markedsføring er blitt to sider av samme sak. Videre dreier det seg om hvor vanskelig det er å skille det ene fra det andre. Dette ble avdekket til fulle i forbindelse med rettsoppgjørene etter blant annet Vioxx-skandalen. Et annet tema er hvordan industrien i stadig større grad markedsfører diagnoser for å sikre marked og «god helse» for deres egne legemidler.

Forfatteren, David Healy, er professor i psykiatri ved universitetet i Cardiff, Wales. Han er spesialist i psykofarmakologi, men er mest kjent for sitt langvarige engasjement knyttet til at farmasøytisk industri lenge holdt vesentlige opplysninger tilbake hva angikk effekt og sikkerhet av SSRI-preparatene, for eksempel opplysninger om at flere av midlene økte selvmordsfaren, spesielt blant barn og unge.

I Pharmageddon dokumenterer forfatteren de mørke sidene knyttet både til SSRI-forskningen og forskningen rundt de «atypiske» antipsykotiske legemidlene Risperdal og Zyprexa, protonpumpehemmere, statiner, antidiabetika og osteoporosemidler med videre. Hvert kapittel er forsynt med referanser for den som vil gå forfatteren nærmere etter i sømmene. Og det bør man, for Healy kan virke i overkant polemisk her og der. Men her er så mange alarmerende faktaopplysninger at man ikke kan feie boken under teppet. Healy hevder for eksempel at nær $30 \%$ av alle gjennomførte kliniske legemiddelstudier aldri blir publisert, typisk når resultatene faller negativt ut for sponsorens produkt. Unntaket er når man klarer det kunststykket å gjøre en negativ studie om til en positiv publikasjon. Justert søkelys, justert variabelgruppering eller annen datamanipulering kan gjøre minus til pluss. Og det blir gjort. Ofte. Helproffe medisinske skribenter («ghost writers») i egne firmaer som selger sine tjenester til legemiddelindustrien, spiller en nøkkelrolle her. Storparten av alle multisenterstudier, sponset av industrien, er både analysert og skrevet sammen av «ghost writers» - uten at dette fremgår av publikasjonene. Oppførte forfattere er til dels «guest authors», noen ganger invitert så sent inn i prosessen at forfatterskapet i virkeligheten bare handler om å korrekturlese manuskriptet. Healy understreker at firmakontrollen med forskningen bekreftes av at heller ikke studiens forfattere pleier å få adgang til alle rådataene. I likhet med nasjonale legemiddelmyndigheter må de stole på tabellverket som firmaet har fått utarbeidet. Healy hevder at pasienter som melder seg frivillig til å delta i legemiddelutprøvinger, derfor også føres bak lyset siden de ikke gjøres kjent med at verken forskerne eller myndighetene får tilgang til studiens rådata etter at studien er gjennomført.

Pharmageddon er uhyggelig lesing. Det bildet man sitter igjen med etter lesingen, er langt mer omfattende og alvorlig for forskningens troverdighet enn at en og annen avvikende forsker à la Sudbø fabrikkerer egne resultater.

Denne leseren hadde nok foretrukket en mer samlet fremstilling av historiene knyttet til de ulike medikamentene. Men stikkordregisteret bakerst hjelper bra om man vil samle trådene knyttet til eksempelvis ett bestemt medikament.

Boken er en brannfakkel som utvilsomt vil skape mye debatt. Om den vil medvirke til at Kunnskapssenteret og tilsvarende organisasjoner begynner å skille mellom kommersielle og uavhengige studier i sine kunnskapsoppsummeringer, gjenstår å se. Jeg anbefaler den for alle som er opptatt av klinisk forskning, forskningens troverdighet og vitenskapens kunnskapsgrunnlag.

\section{Jørund Straand}

Avdeling for allmennemedisin Institutt for helse og samfunn

Universitetet i Oslo 